\title{
Detection of Clostridium perfringens Alpha, Epsilon and Clostridium chauvoei A toxin genes in Blackleg
}

\author{
Azam Ali Nasir ${ }^{1}$, Muhammad Usman Ashraf1, Asma Kausar ${ }^{1}$, Nofil Mustafa1, Zain-ul Fatima1, \\ Mobeen Sarwar ${ }^{2}$, Rabia Riaz ${ }^{1}$, Waseem Shahzad ${ }^{1}$, Abdul Khaliq ${ }^{2}$, Riaz Hussain ${ }^{3}$ \\ ${ }^{1}$ Veterinary Research Institute, Lahore Cantt, Pakistan \\ ${ }^{2}$ Provincial Disease Diagnostic Laboratory, Cooper Road, Lahore, Pakistan \\ ${ }^{3}$ College of Veterinary and Animal Sciences, The Islamia University of Bahawalpur, Pakistan
}

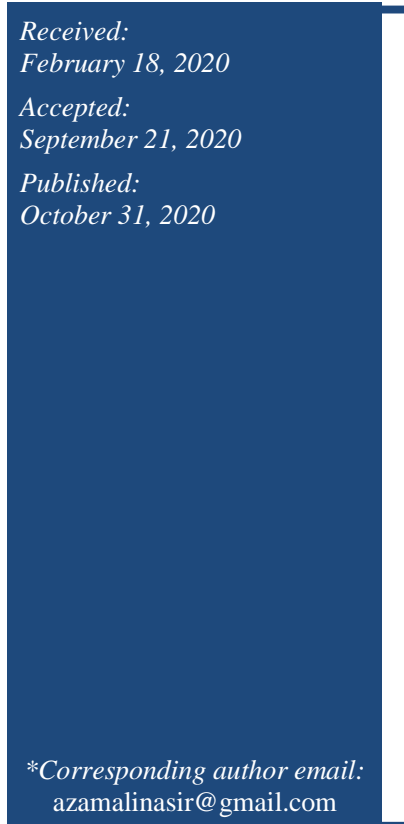

\begin{abstract}
Polymerase Chain Reaction (PCR) detected concurrent infection of Clostridium (C.) perfringens type $\mathrm{D}$ and $C$. chauvoei in samples of three cattle out of five which were submitted to Veterinary Research Institute (VRI) for confirmation of $C$. chauvoei. The animals had a history of fever, lameness and crepitating sound with death occurring within 48 hours after the onset of clinical signs and seemed to be typical cases of black leg. Furthermore, the traditional methods including clinical examination, necropsy findings, cultural and biological methods are not solely enough for the confirmation of disease and are not sufficient to determine the number of pathogens involved in such cases.
\end{abstract}

Keywords: C. chauvoei, C. perfringens type D, Cattle, PCR, Concurrent infection

\section{How to cite this:}

Nasir AA, Ashraf MU, Kausar A, Mustafa N, Fatima Z, Sarwar M, Riaz R, Shahzad W, Khaliq A and Hussain R, 2020. Detection of Clostridium perfringens Alpha, Epsilon and Clostridium chauvoei A Toxin Genes in Blackleg. Asian J. Agric. Biol. 8(4): 519523. DOI: https://doi.org/10.35495/ajab.2020.02.120

This is an Open Access article distributed under the terms of the Creative Commons Attribution 3.0 License. (https://creativecommons.org/licenses/by/3.0), which permits unrestricted use, distribution, and reproduction in any medium, provided the original work is properly cited.

\section{Introduction}

In Pakistan, the livestock animals such as buffaloes, cattle, camels, sheep and goats are known as the cornerstones of livelihood of people of rural areas and usually reared for milk and meat purpose (Ali et al., 2016; Ali et al., 2017; Hussain et al., 2018; Hussain et al., 2020). The dairy animals in Pakistan are mainly kept in tropical and subtropical conditions which contribute substantially $(11.8 \%)$ in gross domestic product (GDP) of the country with 39.7 million cattle (Rehman et al., 2017). However, various infectious problems are the major issues of dairy animals in Pakistan and affect the productivity and food security (Batool et al., 2019; Rashid et al., 2019). The dairy animals in Pakistan suffer from different bacterial (Mahmood et al., 2014a; Mahmood et al., 2017; Hussain et al., 2017), infections (Mahmood et al., 2014b; Hussain et al., 2016; Hussain et al., 2017b; Hussain et al., 2018; Zafar et al., 2019) and viral diseases (Khan et al., 2018; Hussain et al., 2020). Among different bacterial diseases, clostridial infections are the main threats to dairy animals (Hussain et al., 2019). Blackleg disease in cattle and buffalo whereas enterotoxaemia (Pulpy kidney disease) in sheep and goats are of considerable economic importance and caused by $C$. chauvoei (Hussain et al., 2019) and $C$. perfringens type D respectively (Falquet et al., 2013). Clostridia produce a number of potent toxins and enzymes which 
are responsible for the development of various diseases (Rychener et al., 2017). The affected animal with Black leg may harbor the organism in the liver and represents the main epidemiological hazard for the infection and considered as non-traumatic endogenous infection (Casagrande et al., 2015). The affected animal usually shows signs of anorexia, fever, depression, hot painful swelling on affected area, crepitating sound, lameness and death within 12 to 48 hours (Aiello and Moses, 2016). The C. chauvoei have tropism for larger muscles especially thigh, heart and diaphragm which look spongy at necropsy while $C$. perfringens type $\mathrm{D}$, an etiological agent of Enterotoxaemia is a normal inhabitant of intestine but under favorable conditions produce toxins which cause various gastrointestinal infections in most mammalian species. (Gacem et al., 2015). The diagnosis of black leg is established traditionally by history, clinical signs and gross lesions coupled with cultural and biological method.

The previous studies showed that the $C$. chauvoei is a usual etiological agent of Black leg in cattle and in certain cases combined with $C$. septicum whereas, the current findings revealed presence of $C$. perfringens type D alpha (cpa) and epsilon (etx) toxin genes which is unusual in gluteal muscles along with $C$. chauvoei toxin A (CctA) gene by PCR in three cases which were submitted only for the confirmation of black leg disease.

\section{Material and Methods}

The study included $(n=5)$ samples of gluteal muscle pieces from cattle suspected for Black leg disease and were submitted immediately after death to avoid any contamination for its confirmation at VRI, Lahore Pakistan during 2016-2018. The animals were between 10-26 months of age and suspected for Black leg only. The death occurred within 48 hours after the onset of clinical signs. The impression smears from muscle pieces were prepared and simultaneously cultured in Cooked Meat Broth Medium (CMBM) for morphological examination. The blood agar plates were inoculated with growth taken from CMBM and kept under anaerobic conditions at $37^{\circ} \mathrm{C}$ for 48 hours (Abreu et al., 2017). The colonies from blood agar plates were picked and used for molecular identification.

The bacterial DNA was extracted by phenol chloroform isoamyl alcohol method (Eslami et al., 2017) and the polymerase chain reaction (PCR) was performed in $25 \mathrm{ul}$ volume and the molecular detection of $C$. perfringens type D, C. chauvoei and C. septicum was performed by amplification of the genes (Table 1). Briefly, the amplification was carried out in a thermal cycler (Biorad) using 30 cycles of $95^{\circ} \mathrm{C}, 55^{\circ} \mathrm{C}$ and 72 ${ }^{\circ} \mathrm{C}$ for 45 seconds each for cpa and etx gene, $94^{\circ} \mathrm{C}$, $46^{\circ} \mathrm{C}$ and $72^{\circ} \mathrm{C}$ for one minute each for C. chauvoei toxin gene $\mathrm{A}(C \operatorname{CtA})$ and $94^{\circ} \mathrm{C}, 55^{\circ} \mathrm{C}$ and $72^{\circ} \mathrm{C}$ for one minute each for $C$. septicum gene. The initial denaturation at $95^{\circ} \mathrm{C}$ for 5 minutes and final extension at $72{ }^{\circ} \mathrm{C}$ for 10 minutes was carried for amplification of all the genes. The amplified DNA fragments were examined by electrophoresis in a $1.5 \%$ agarose gel and visualized by UV transillumination.

Table-1. Specific primers along with their target genes

\begin{tabular}{|c|c|c|c|c|}
\hline Toxin gene & Primers & Sequence $\left(5^{\prime}-3^{\prime}\right)$ & $\begin{array}{c}\text { Fragment } \\
\text { Length }\end{array}$ & Reference \\
\hline cpa & $\begin{array}{l}\text { PL3 } \\
\text { PL7 }\end{array}$ & \begin{tabular}{|l} 
AAGTTACCTTTGC \\
TGCATAATCCC \\
\\
ATAGATACTCCA \\
TATCATCCTGCT
\end{tabular} & $283 b p$ & $\begin{array}{l}\text { (Fach and } \\
\text { Popoff, } \\
1997 \text { ) }\end{array}$ \\
\hline etx & $\begin{array}{l}1 \\
2\end{array}$ & \begin{tabular}{|c|} 
GCGGTGATATCC \\
ATCTATTC \\
CCACTTACTTGTC \\
CTACTAAC \\
\end{tabular} & $655 \mathrm{bp}$ & $\begin{array}{l}\text { (Marina et } \\
\text { al., 2008) }\end{array}$ \\
\hline $\begin{array}{l}\text { C. chauvoei } \\
\text { CctA }\end{array}$ & $\begin{array}{l}\text { CCTO2AL } \\
\text { CCTO2AR }\end{array}$ & $\begin{array}{c}\text { AGTGAAGGAGTA } \\
\text { AAGACTTTTATTA } \\
\text { ATAT } \\
\text { CCTGCATGCTCA } \\
\text { ACAG } \\
\end{array}$ & $1400 \mathrm{bp}$ & $\begin{array}{l}\text { (Idrees et } \\
\text { al., 2014) }\end{array}$ \\
\hline C. septicum & $\begin{array}{l}\text { Hemolysin } \\
\text { gene }\end{array}$ & \begin{tabular}{|c|} 
AATTCAGTGTGC \\
GGCAGTAG \\
CCTGCCCCAACTT \\
CTCTTTT
\end{tabular} & $270 b p$ & $\begin{array}{l}\text { (Takeuchi } \\
\text { et al., } \\
\text { 1997) }\end{array}$ \\
\hline
\end{tabular}

\section{Results and Discussion}

The history and clinical findings with death of animals lead to a presumptive diagnosis of black leg disease. The microscopic examination from CMBM culture and impression smear from muscle pieces revealed gram positive rods of variable size with central and sub terminal spores (Figure 1). The colonies of grayish white appearance with zone of hemolysis on blood agar were seen.

The PCR detected both $C$. perfringens type D cpa and etx encoding gene of $283 \mathrm{bp}$ and $655 \mathrm{bp}$ respectively while $C c t A$ encoding gene for $C$. chauvoei of $1400 \mathrm{bp}$ on agarose gel in three samples (Figure 2). However, Hemolysin gene of $C$. septicum was not detected from any sample (Table 2). 


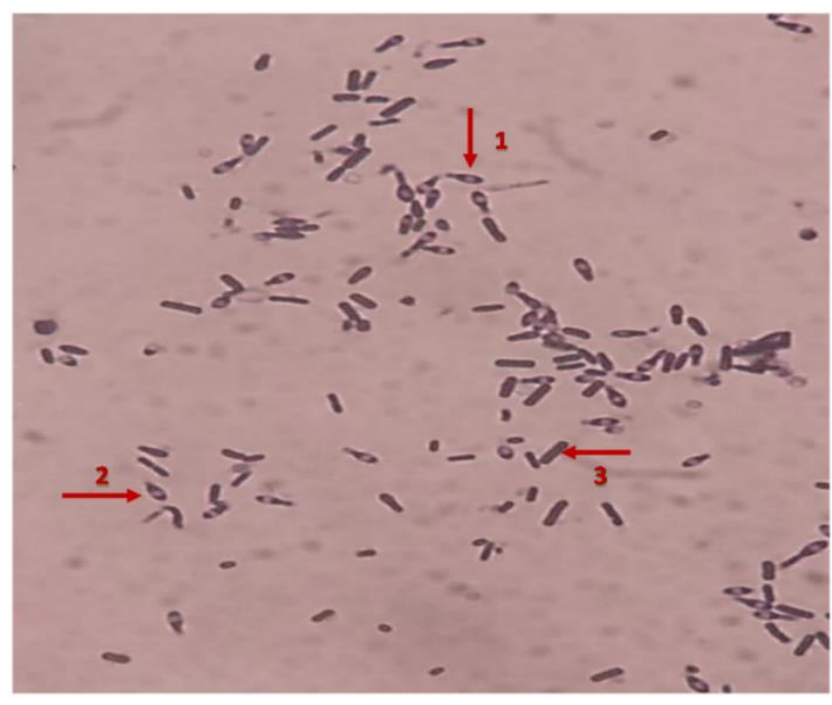

Figure-1. Gram's staining (x100) 1: sub-terminal spore, 2: central spore 3: thick cylindrical Gram-positive rod

Table-2. Sample No. with age in months and amplification of different toxin genes

\begin{tabular}{|c|c|c|c|c|c|}
\hline $\begin{array}{c}\text { Sample } \\
\text { No. }\end{array}$ & $\begin{array}{c}\text { Age in } \\
\text { Months }\end{array}$ & cpa & etx & CctA & $\begin{array}{c}\text { C.septicum } \\
\text { Hemolysin gene }\end{array}$ \\
\hline 1 & 10 & + & + & + & - \\
\hline 2 & 12 & - & - & + & - \\
\hline 3 & 12 & + & + & + & - \\
\hline 4 & 26 & + & + & + & - \\
\hline 5 & 26 & - & - & + & - \\
\hline
\end{tabular}

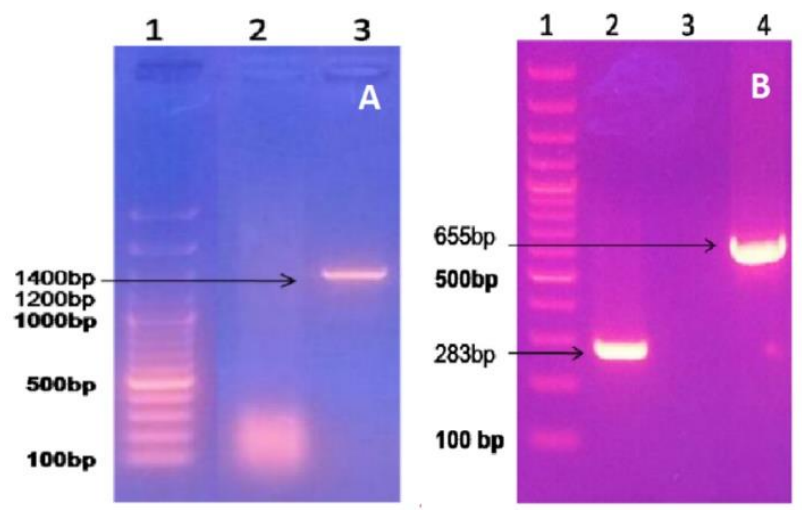

Figure-2. (A) PCR amplification of CctA encoding gene $1400 \mathrm{bp}$ can be visualized on agarose gel (B) PCR amplification of cpa encoding gene $283 \mathrm{bp}$ and etx encoding gene 655 bp can be visualized on agarose gel.

Blackleg is highly fatal for cattle commonly affecting animals younger than 24 months of age and caused by C. chauvoei and is linked to virulence factors especially Hemolysins which includes $\operatorname{Cct} \mathrm{A}$ and chauveolysin (Popoff, 2016) but the role of DNAse,
Hyaluronidase and Neuramindase in disease progression is less well described. C. chauvoei DNAse is responsible for the degradation of DNA while Hyaluronidase cleaves hyalurone which is essential component of extracellular matrix, resulting in loosening of tissue and facilitate the spread of pathogen while Neuraminadase acts on host cell surface and decreases the rigidity of cell membrane and degrade the tight junction by cleaving the sialic acid (Frey and Falquet, 2015). The circulation of hemolysins in blood stream results in cytolysis and hemolysis causing typical lesions of Black Leg (Popoff, 2016; Abreu et al., 2017). A mixed infection of $C$. chauvoei with $C$. perfringens type A, $C$. septicum, $C$. novyi and $C$. sordellii have been reported during a retrospective study for the diagnosis of clostridial myonecrosis in ruminants (Pires et al., 2017) whereas only $C$. perfringens was detected instead of $C$. chauvoei in two calves with typical signs of Black Leg (Askari et al., 2016). The amplification of cpa and etx genes which are specific for $C$. perfringens type $\mathrm{D}$ from muscle pieces was certainly surprising during present study as this bacterium inhabits the large intestine of sheep and goats but not muscles. It seems that the spores of $C$. perfringens type $\mathrm{D}$ were ingested, absorbed, transported and lodged in various tissues including the gluteal muscles. The clinico-pathological findings in different tissues have been recorded in goats experimentally infected with $C$. perfringens type $\mathrm{D}$ along with molecular detection of cpa and etx genes (Nasir et al., 2015). The previous studies revealed that $C$. perfringens type $\mathrm{D}$ has affinity for gastrointestinal tract while $C$. chauvoei target especially heavy muscles. However, the finding of the current study suggests that $C$. perfringens type D not only targets the alimentary tract but can invade muscle tissues as well. It would have not been possible to detect $C$. perfringens type D toxin genes if only traditional approach for the diagnosis of Black leg was followed.

\section{Conclusion}

The identification of $C$. perfringens specifically type D cpa and etx along with C. chauvoei CctA gene from blackleg case in cattle is an unusual finding. However, further experimental study is needed to find out the pathogenic role of $C$. perfringens type $\mathrm{D}$ alone and in combination with $C$. chauvoei for the progression of disease. 
Disclaimer: None.

Conflict of Interest: None.

Source of Funding: None.

\section{References}

Abreu CC, Edwards EE, Edwards JF, Gibbon PM, Leal-de-Araujo J, Rech RR and Uzal FA, 2017. Blackleg in cattle: a case report of fetal infection and a literature review. J. Vet. Diag. Invest. 29: 612-621.

Aiello SE and Moses MA, 2016. The Merck Veterinary Manual, $11^{\text {th }}$ ed. Wiley, USA.

Ali F, Hussain R, Qayyum A, Gul ST, Iqbal Z and Hassan MF, 2016. Milk somatic cell counts and some hemato-biochemical changes in sub-clinical mastitic dromedary she-camels (Camelus dromedarius). Pak. Vet. J., 36: 405-408.

Ali HM, Qureshi AS, Hussain R, Urbinati G, Mustafa MZ, Ali F, Manan A and Massaad-Massade L, 2017. Effects of natural environment on reproductive histo-morphometric dynamics of female dromedary camel. Anim. Reprod. Sci. 181: $30-40$.

Askari N, Ghanbarpour R, Kheirandesh R, Tajik J and Alimolaei M, 2016. Detection of Clostridium perfringens bacterium in the clinical specimens from blackleg calves: a report of two cases. Comp. Clin. Pathol. 26: 255-259.

Batool M, Nasir S, Rafiq A, Yousaf I and Yousaf M, 2019. Prevalence of tick infestation in farm animals from Punjab, Pakistan. Pak. Vet. J. 39: 406-410.

Casagrande RA, Pires PS, Silva ROS, Sonne L, Borges JBS, Neves MS, Rolim VM, Desouza SO, Driemeier D and Lobato FCF, 2015. Histopathological, immunohistochemical and biomolecular diagnosis of myocarditis due to Clostridium chauvoei in bovine. Ciencia Rural. 45:1472-1475.

Eslami G, Khalatbari-Limaki S, Ehrampoush MH, Gholamrezeal M, Hajimohammadi B and Oryan A, 2017. Comparison of three different DNA Extraction Methods of Linguatula serrate as a food borne Pathogen. Iraq J. Parasitol. 12: 236-243.

Fach P and Popoff MR, 1997. Detection of enterotoxigenic Clostridium perfringens in food and fecal samples with a duplex PCR and the slide latex agglutination test. Appl. Environ. Microbiol. 63: 4232-4236.

Falquet L, Calderon-Copete and Frey J, 2013. Draft genome sequence of the virulent Clostridium chauvoei reference strain JF4335. Genome Announc. 01: 001.

Frey J and Falquet L, 2015. Patho-genetics of Clostridium chauvoei. Res. Microbiol. 166: 384392.

Gacem F, Madadi MA, Khecha N and Bakour R, 2015. Study of vaccinal properties of Clostridium chauvoei strains isolated during a black leg outbreak in cattle in Algeria. Kafkas Univ. Vet. Fak. Derg. 21: 825-829.

Hussain R, Javed MT, Khan I, Siddique AB, Aslam B, Ghaffar A, Tariq N, Qayyum A and Wareth G, 2019. Pathological and clinical investigations of an outbreak of Blackleg disease due to C. chauvoei in cattle in Punjab, Pakistan. J. Infect. Dev. Count. 13: 786-793.

Hussain R, Khan A, Abbas RZ, Ghaffar A, Abbas G, Rahman T and Ali F, 2016. Clinico-Hematological and Biochemical Studies on Naturally Infected Camels with Trypanosomiasis. Pak. J. Zool. 48: 311-316.

Hussain R, Khan A, Jahanzaib, Qayyum A, Abbas T, Ahmad M, Mohiuddin M, and Mehmood K, 2018. Clinico-hematological and oxidative stress status in Nili Ravi buffaloes infected with Trypanosoma evansi. Microb. Pathog. 123: 126-131.

Hussain R, Mahmood F, Ali HM and Siddique AB, 2017. Bacterial, PCR and clinico-pathological diagnosis of naturally occurring pneumonic pasturellosis (mannheimiosis) during subtropical climate in sheep. Microb. Pathog. 112: 176e181.

Hussain R, Mahmood F, Aslam B, Siddique AB, Rafique A, Khaliq SA, Khan I, Imran S, Mubeen M, Jahanzaib and Nasir AA, 2020. Investigation of different serotypes of FMDV in vaccinated Buffaloes (Bubalus bubalis) in Southern Areas of Punjab Province, Pakistan. Pak. Vet. J. 40: 118122.

Hussain R, Mahmood F, Khan A and Mehmood K, 2017b. Prevalence and pathology of bovine coccidiosis in Faisalabad district, Pakistan. Thai. J. Vet. Med. 47: 401-406.

Idrees A, Chaudary ZI, Younus M and Ashraf K, 2014. Isolation and molecular detection of Clostridium chauvoei alpha toxin gene from clinical cases of Black quarter in cattle. J. Anim. Plant Sci. 24: 755759.

Khan A, Saleemi MK, Ali F, Abubakar M, Hussain R, Abbas RZ and Khan IA, 2018. Pathophysiology of peste des petits ruminants in sheep (Dorper \& Kajli) and goats (Boer \& Beetal). Microb. Pathog. 
117: 139-147.

Mahmood F, Khan A, Hussain R and Anjum MS, 2014b. Prevalence and pathology of dictyocalus viviparous infection in cattle and buffaloes. J. Anim. Plant. Sci. 24: 743-748.

Mahmood F, Khan A, Hussain R and Khan IA, 2014a. Molecular based epidemiology of bovine pulmonary tuberculosis - a mortal foe. Pak. Vet. J. 34: 185-188.

Mahmood F, Khan A, Hussain R, Khan IA, Abbas RZ, Ali HM and Younus M, 2017. Pathobacteriological investigation of an outbreak of Mycoplasma bovis infection in calves - Emerging stealth assault. Microb. Pathog. 107: 404-408.

Marina CF, Tereza CC and Iveraldo SD, 2008. Genotyping of Clostridium perfringens isolated from calves with neonatal diarrhea. Anaerobe. 24: 328-331.

Nasir AA, Younus M, Rashid A, Abdul Khaliq S, Khan E, Shah SH, Aslam A, Ghumman MA and Joiya MH, 2015. Clinico-pathological findings of Clostridium perfringens type D enterotoxemia in goats and its hemolytic activity in different erythrocytes. IJVR. 16: 94-99.

Pires PS, Ecco R, Silva ROS, Araujo MR, Salvarani FM, Heneine LGD, Junior CAO and Lobato FCF, 2017. A retrospective study on the diagnosis of clostridial myonecrosis in ruminants in Brazil. Cien. Rur. Santa Maria. 47: 1-5.

Popoff MR, 2016. Toxins of histotoxic clostridia: Clostridium chauvoei, Clostridium septicum, Clostridium novyi and Clostridium sordellii pp. 2143 In John Willey \& Sons $\left(1^{\text {st }}\right)$. Clostridial diseases of animals. John Willey \& Sons Inc. Hoboken, New Jersey, USA.

Rashid I, Saqib M, Ahmad T and Sajid MS, 2019. Sero-prevalence and associated risk factors of $\mathrm{Q}$ fever in cattle and buffaloes managed at institutional dairy farms. Pak. Vet. J. 39: 221-225.

Rehman A, Jingdong L, Chandio AA and Hussain I, 2017. Livestock production and population census in Pakistan: Determining their relationship with agricultural GDP using econometric analysis
Inform. Process Agricul, 4 (2): 168-177.

Rychener L, Inalbon S, Djorjevic SP, Chowdhury PR, Nicholson P, Ziech RE, Devargas AC, Frey J and Falquet L, 2017. Clostridium chauvoei, an evolutionary dead-end pathogen. Front. Microbiol. 8: 01-13.

Takeuchi S, Hashizume N, Kinoshita T, Kaidoh T and Tamura Y, 1997. Detection of Clostridium septicum Hemolysin gene by Polymerase Chain Reaction. J. Vet. Med. Sci. 59: 853-855.

Zafar A, Khan MK, Sindhu ZUD, Abbas RZ, Masood S, Abbas Z, Mahmood MS, Saleemi MK, Khan JA, Hussain R, Naseer MU, Iqbal Z, and Javed H, 2019. Seroprevalence of Fasciola hepatica in small ruminants of District Chakwal, Punjab, Pakistan. Pak. Vet. J. 39: 96-100.

\section{Contribution of Authors}

Nasir AA: Conceived idea, designed research methodology, collected and analysed data and wrote manuscript

Ashraf MU: Designed research methodology, collected and analysed data and wrote manuscript Kausar A: Designed research methodology, collected and analysed data and wrote manuscript Mustafa N: Designed research methodology, collected and analysed data and wrote manuscript Fatima Z: Designed research methodology, collected and analysed data and wrote manuscript Sarwar M: Data collection, analysis and interpretation

Riaz R: Data collection, analysis and interpretation

Shahzad W: Literature review, edited and gave final approval of manuscript

Khaliq A: Designed research methodology, collected and analysed data and wrote manuscript Hussain R: Literature review, edited and gave final approval of manuscript 